Biochimica et Biophysica Acta, 398 (1975) 401-414

( Elsevier Scientific Publishing Company, Amsterdam - Printed in The Netherlands

BBA 56651

\title{
DELIPIDATION OF THE PHOSPHATIDYLCIIOLINE EXCHANGE PROTEIN FROM BEEF LIVER BY DETERGENTS
}

\author{
H.H. KAMP, K.W.A. WIRTZ and L.L.M. VAN DEENEN
}

Laboratory of Biochemistry, State University of Utrecht, University Centre "De Uithof", Padualaan 8, Utrecht (The Netherlands)

(Received February 12th, 1975)

\section{Summary}

1. A method is described to introduce $\left[{ }^{14} \mathrm{C}\right]$ phosphatidylcholine into the phosphatidylcholine exchange protein from beef liver. The effects of various detergents on this ${ }^{14} \mathrm{C}$-labelled phospholipid - protein complex are considered.

2. As shown by spectrophotometric and radioactivity analysis of polyacrylamide gels, sodium deoxycholate, Triton X-100, lysophosphatidylcholine and sodium dodecyl sulfate delipidate the exchange protein, while mixed phosphatidylcholine-detergents micelles are formed.

3. Protein delipidated by sodium deoxycholate, Triton X-100 and lysophosphatidylcholine retains its ability to catalyze the transfer of phosphatidylcholine between membranes. The immunological properties are similar to those of native protein as shown by double immunodiffusion in agar against an antiserum $\gamma$-globulin fraction.

4. Sodium dodecyl sulfate and cetyltrimethylammonium bromide interact very strongly with the protein conferring their charge to the complex and destroying the antigenic determinants.

\section{Introduction}

In recent years a large body of information has accumulated on the interaction of detergents with soluble proteins [1-5]. Two types of interaction involving large quantities of detergent may be discerned. On one hand, detergents may associate cooperatively with proteins resulting in denaturation. This reaction occurs with all proteins and involves those detergents which have a relatively high critical micelle concentration, like sodium dodecyl sulfate [2] and cetyltrimethylammonium bromide [4]. On the other hand, detergents may associate in relatively large amounts with proteins which have been part of 
lipid · protein complexes. This type of interaction, which has been studied with sodium deoxycholate and Triton X-100, occurs only with hydrophobic proteins [5]. These latter detergents have been frequently used in the solubilization of membrane-bound proteins [6,7].

It is a matter of intense research by what mechanism detergents act on lipid - protein complexes. Detergent monomer molecules are thought to interact with the complex competing with lipids for the hydrophobic protein sites. At a sufficiently high detergent concentration, the lipid - protein complex dissociates into soluble hydrophobic protein-detergent micelles and mixed lipiddetergent micelles. A complete separation of protein and lipid has been achieved with biological membranes [8-11] and serum lipoproteins [12].

Recently we have isolated from beef liver a protein which has the conspicuous feature of one molecule of phosphatidylcholine noncovalently bound per molecule of protein $[13-16]$. The protein acts as a carrier of phosphatidylcholine between membranes by exchanging its bound phosphatidylcholine molecule for one present in the membrane [15]. In order to obtain information on the lipid-protein interactions within the phosphatidylcholine exchange protein we have investigated the effect of ionic and non-ionic detergents, by using polyacrylamide gel electrophoresis and agar gel immunodiffusion.

In the present study it will be shown that sodium deoxycholate, Triton $\mathrm{X}-100$, sodium dodecyl sulfate and lysophosphatidylcholine, above the critical micelle concentration, dissociate the exchange apoprotein - phosphatidylcholine complex. In an accompanying paper the effect of detergents below the critical micelle concentration and organic solvents on the exchange protein will be discussed [17].

\section{Materials and Methods}

Phosphatidylcholine exchange protein was purified from beef liver as previously described [14]. Phosphatidylcholine was isolated from egg yolk according to established procedures [18]. A $\left[{ }^{14} \mathrm{C}\right]$ methyl group was introduced into the polar headgroup of phosphatidylcholine by a slight modification of the method of Stoffel et al. [19]. Methylation was performed in the presence of tetrahydrofurane and cyclohexylamine. The methylating agent, $\left[{ }^{14} \mathrm{C}\right]$ methyliodide, was obtained from the Radiochemical Centre, Amersham, U.K. Purity of $\left[{ }^{14} \mathrm{C}\right]$ phosphatidylcholine has been checked by thin-layer chromatography. Lysophosphatidylcholine was prepared by degradation of phosphatidylcholine with phospholipase $\mathrm{A}_{2}$ from Crotalus adamanteus (Sigma, U.S.A.) [20]. The following detergents were used without further purification: sodium deoxycholate (Mcrck, Germany), Triton X-100 (Rohm and Haas, U.S.A.), sodium dodecyl sulfate (Koch-Light, U.S.A.) and cetyltrimethylammonium bromide (Merck, Germany).

\section{Preparation of $\left[{ }^{14} \mathrm{C}\right]$ phosphatidylcholine exchange protein}

$\left[{ }^{14} \mathrm{C}\right]$ phosphatidylcholine $(40 \mathrm{nmol}$, spec. act. $62 \mathrm{Ci} / \mathrm{mol})$ was dissolved in chloroform/methanol $(1: 1$, by vol.) and transferred to a small conical tube. The solvent was evaporated under a stream of nitrogen. Liposomes were then routinely prepared by suspending the lipid residue in $1 \mathrm{ml} 0.05 \mathrm{M}$ Tris- 
$\mathrm{HCl} / 0.05 \mathrm{M} \mathrm{NaCl} / 0.02 \% \mathrm{NaN}_{3}(\mathrm{pH} 7.4)$ and sonicating for $2 \mathrm{~min}$ with a Branson sonifier at $50 \mathrm{~W}$ output. Exchange protein $(20 \mathrm{nmol}$ in $4 \mathrm{ml} 50 \%$ glycerol) was added to the liposome suspension and incubated for $30 \mathrm{~min}$ at $37^{\circ} \mathrm{C}$. After incubation, protein and liposomes were separated on a Sephadex G-75 column $\left(57 \times 1.5 \mathrm{~cm}\right.$ ) in the Tris $/ \mathrm{NaCl} / \mathrm{NaN}_{3}$ buffer by upward flow (flow rate: $6 \mathrm{ml}$ per $\mathrm{h}$ ). Aliquots $(25 \mu \mathrm{l})$ of each fraction $(2 \mathrm{ml})$ were mixed with $15 \mathrm{ml}$ dioxane ( $10 \%$ naphthalene, $0.7 \%$ PPO, $0.03 \%$ POPOP).

Radioactivity was measured with a Packard Tricarb liquid scintillation spectrometer. The fractions containing ${ }^{14} \mathrm{C}$-labelled protein were pooled. Protein was determined with the method of Lowry et al. [21] using bovine serum albumin as a standard. The specific radioactivity of the $\left[{ }^{14} \mathrm{C}\right]$ phosphatidylcholine exchange protein was approx. $15 \mathrm{Ci} / \mathrm{mol}$ of protein. Subsequently, the pooled radioactive protein fractions were concentrated against $30 \%$ Sucrose/ 0.01 Tris- $\mathrm{HCl}(\mathrm{pH} 7.4)$.

\section{Detergent treatment}

$\left[{ }^{14} \mathrm{C}\right]$ phosphatidylcholine exchange protein $(30 \mu \mathrm{g}$ protein $)$ was incubated for $45 \mathrm{~min}$ at $37^{\circ} \mathrm{C}$ in a total volume of $0.35 \mathrm{ml} 30 \%$ sucrose $/ 0.01 \mathrm{M}$ Tris- $\mathrm{HCl}(\mathrm{pH} \mathrm{7.4)}$ with the desired concentration of detergent. After incubation $0.01 \mathrm{ml}$ of $0.025 \%$ bromophenol blue (Merck, Germany) was added and aliquots $(150 \mu \mathrm{l})$ were applied to duplicate polyacrylamide gels. One gel was used for spectrophotometric scanning; the other one for radioactive tracing (see below).

\section{Polyacrylamide gel electrophoresis}

Electrophoresis was performed according to the method of Davis [22]; the buffer front was indicated by bromophenol blue. Electrophoresis was carried out for $1 \mathrm{~h}$ with $4 \mathrm{~mA}$ per tube. Gels were fixed in $10 \%$ trichloroacetic acid for $1 \mathrm{~h}$ at $65^{\circ} \mathrm{C}$, washed in methanol/acetic acid/ $\mathrm{H}_{2} \mathrm{O}(5: 1: 5$, by vol.) and stained with $0.25 \%$ Coomassie Brilliant Blue R 250 (Serva, Germany). Excess stain was removed by washing in $7 \%$ acetic acid. Scanning of the gels at $600 \mathrm{~nm}$ was performed on a Zeiss spectrophotometer.

To determine the distribution of ${ }^{14} \mathrm{C}$ radioactivity, gels were frozen immediately after electrophoresis on a aluminium plate cooled with dry ice. The gel was then divided into 1- or 2-mm segments with a transverse slicer as described by Matsumura and Noda [23]. The slices were dissolved in $30 \%$ hydrogen peroxide $(250 \mu \mathrm{l})$ at $50^{\circ} \mathrm{C}$ for $4 \mathrm{~h}$. The samples were mixed with 15 $\mathrm{ml}$ dioxane (10\% naphthalene, $0.7 \%$ PPO, $0.03 \%$ POPOP) and radioactivity was determined.

Sodium dodecyl sulfate-polyacrylamide gel electrophoresis was performed according to the method of Weber and Osborn [24]. Fixation, staining, scanning and slicing of the gels were performed as described above. Molecular weights of the proteins were calculated as described previously [14].

\section{Immunological studies}

A $\gamma$-globulin fraction of the rabbit antiserum against the phosphatidylcholine exchange protein was prepared as described before [25]. Double immunodiffusion was performed in $0.8 \%$ agar gels (Difco Laboratories, U.S.A.) contain- 
ing $0.025 \mathrm{M}$ sodium acetate/sodium barbital ( $\mathrm{pH} 8.6)$ as described by Clausen [26]. After the precipitin lines became visible, the gels were washed for 3 days with $0.9 \% \mathrm{NaCl}$ and 1 day with water. Staining was done with Coomassie Brilliant Blue as described above for the polyacrylamide gels.

\section{Phosphatidylcholine exchange activity}

Exchange activity of protein samples treated with detergent was determined with a slight modification of the liposomeliposome assay as describcd by Hellings et al. [27]. The catalyzed transfer of $\left[{ }^{14} \mathrm{C}\right]$ phosphatidylcholine was measured by incubating ${ }^{14} \mathrm{C}$-labelled donor liposomes $(0.250 \mu \mathrm{mol}$ phosphatidylcholine, $8 \mathrm{~mol} \%$ phosphatidic acid) with ${ }^{3} \mathrm{H}$-labelled acceptor liposomes $(0.625 \mu \mathrm{mol}$ phosphatidylcholine, $2 \mathrm{~mol} \%$ phosphatidic acid) for $30 \mathrm{~min}$ at $37^{\circ} \mathrm{C}$ in $1.5 \mathrm{ml} 0.0125 \mathrm{M}$ sodium phosphate buffer $(\mathrm{pH}, 7.2)$.

\section{Results}

\section{$\left[{ }^{14} \mathrm{C}\right]$ phosphatidylcholine exchange protein}

The exchange protein is labelled with $\left[{ }^{14} \mathrm{C}\right]$ phosphatidylcholine upon incubation with ${ }^{11} \mathrm{C}$-labelled phosphatidylcholine liposomes and chromatography on Sephadex G-75. A typical elution pattern is shown in Fig. 1. The liposomes appear in the void volume, while the protein elutes at 1.7-times the void volume, in agreement with its mol. wt of 22000 [28]. Recovery of the protein was approx. $90 \%$; recovery of liposomal phosphatidylcholine was in the order of $50 \%$ due to aspecific adsorption to the Sephadex matrix.

Electrophoresis of the ${ }^{14} \mathrm{C}$-labelled exchange protein on polyacrylamide gels according to the method of Davis [22] gave two bands with $R_{\mathrm{F}}$ values of 0.25 and 0.31 respectively (Fig. 2). This pattern is also observed with unla-
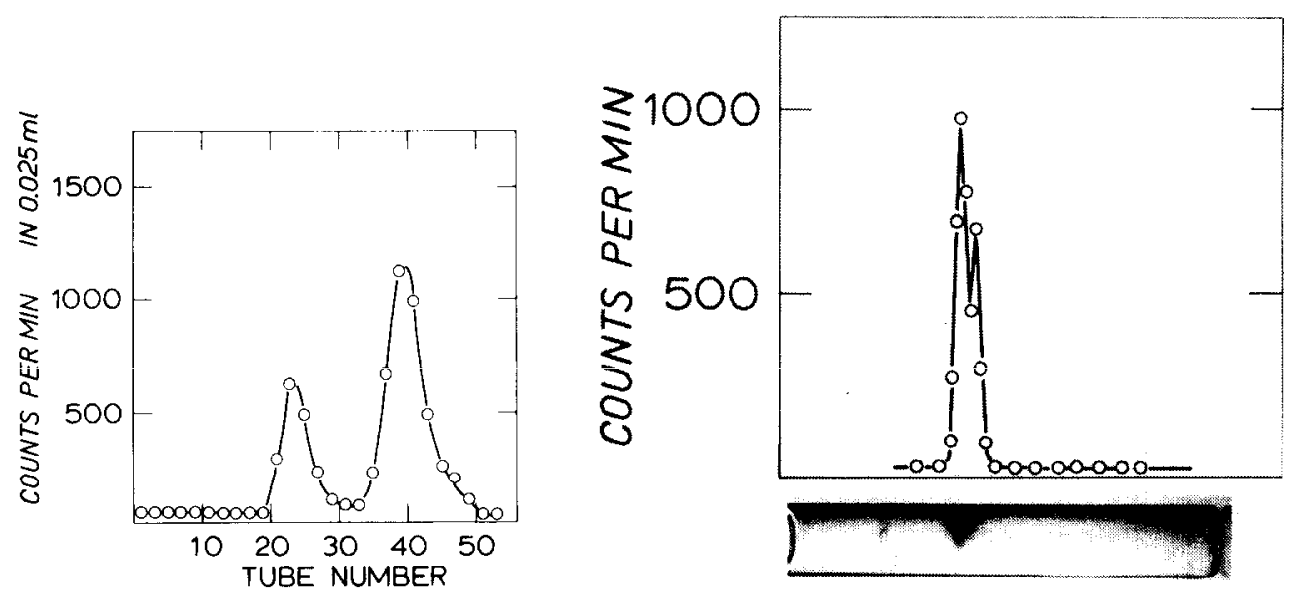

Fig. 1. Separation of $\left[{ }^{14} \mathrm{C}\right]$ phosphatidylcholine exchange protein from ${ }^{14} \mathrm{C}$-labelled liposomes on Sephadex G-75. For experimental details see Materials and Methods. The void volume containing the liposomes is indicated by tube number 23 .

Fig. 2. Polyacrylamide gel electrophoresis of $\left[{ }^{14} \mathrm{C}\right]$ phosphatidylcholine exchange protein $(15 \mu \mathrm{g})$ according to Davis [22]. Electrophoresis was performed for $60 \mathrm{~min}$ at $4 \mathrm{~mA}$ per gel. Staining, slicing and analyzing for radioactivity is described in Materials and Methods. 


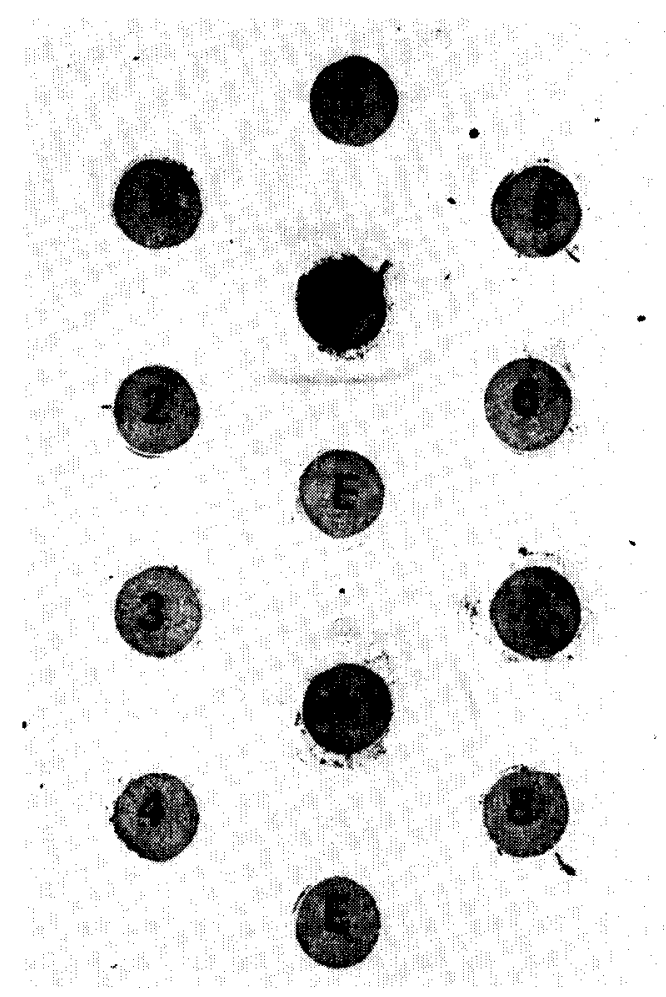

Fig. 3. Double immunodiffusion on agar of phosphatidylcholine exchange protein after polyacrylamide gel electrophoresis $(20 \mu \mathrm{g}$ of protein). The gel was divided into $1-\mathrm{mm}$ slices. Slices were transferred to Wells $1-8$. Well 1 contained the slice with $R_{\mathrm{F}}$ of 0.22 and Well 8 the slice with an $R_{\mathrm{F}}$ of 0.38 . Well $\mathrm{E}$ contained $2 \mu \mathrm{g}$ of exchange protein that was not subjected to electrophoresis. Well A contained $125 \mu \mathrm{g}$ of a $\gamma$-globulin fraction of a rabbit antiserum.

belled protein and is thought to be a consequence of oxidative damage during electrophoresis [29]. Prerunning of the gel or preincubation of the gel in $0.050 \mathrm{M}$ cysteine results in the disappearance of the band at $R_{\mathrm{F}}=0.31$. It is shown in Fig. 2 that both bands are radiolabelled, indicating that the alterations introduced by electrophoresis does not interfere with the binding of $\left[{ }^{14} \mathrm{C}\right]$ phosphatidylcholine to the protein. In an additional experiment a polyacrylamide gel comparable to the one shown in Fig. 2 was sliced without previous staining. Those slices which would be expected to contain the two protein bands, were used in double immunodiffusion against the $\gamma$-globulin antiserum fraction ( Fig. 3). All slices between $R_{\mathrm{F}} \quad 0.24-0.35$ gave precipitin lines (Wells 2-7). Thus, gel electrophoresis had no adverse effect on the immunochemical reactivity of either protein band. It will become evident from the experiments shown below that the formation of a second protein band due to electrophoresis does not hamper the interpretation of the results.

\section{Effect of sodium deoxycholate}

The effect of sodium deoxycholate on $\left[{ }^{14} \mathrm{C}\right]$ phosphatidylcholine exchange protein as analyzed by polyacrylamide gel electrophoresis is shown in 

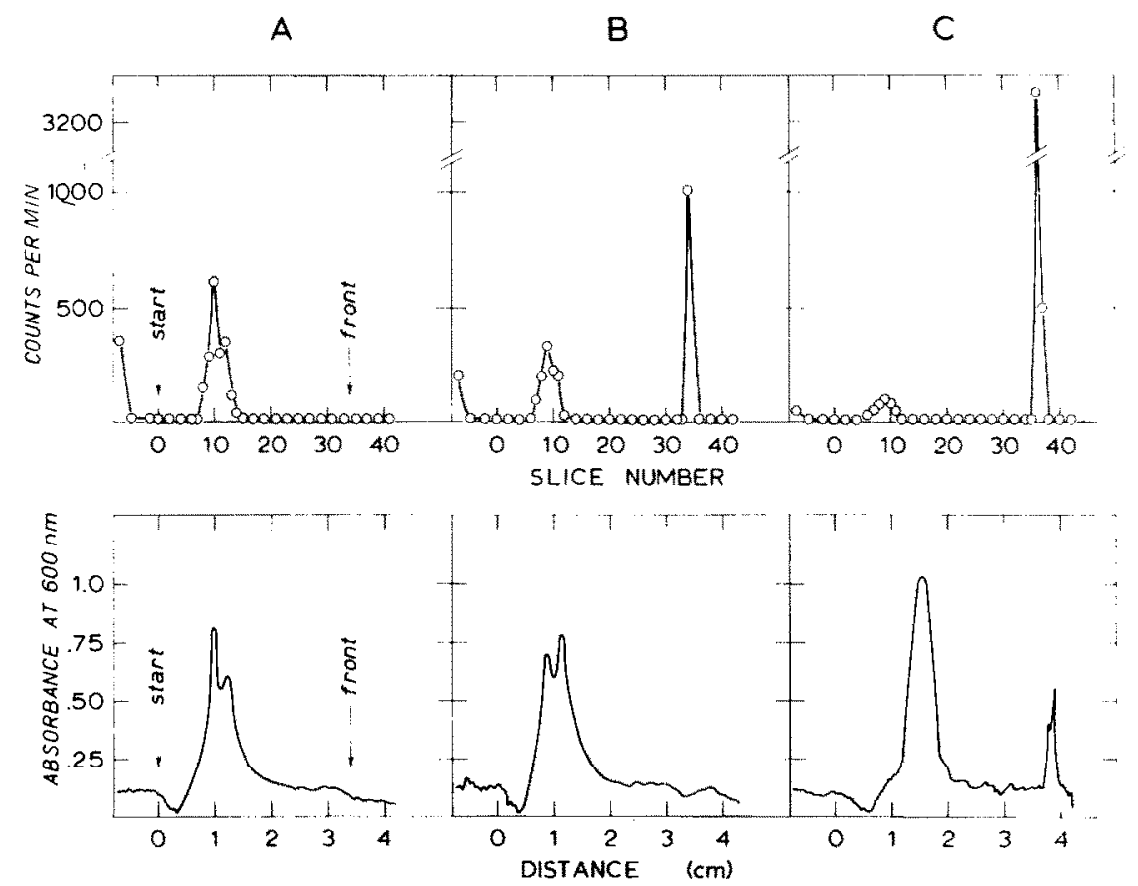

Fig. 4. Effect of sodium deoxycholate on $\left[{ }^{14} \mathrm{C}\right]$ phosphatidylcholine exchange protein as analyzed by radioactive tracing (upper) and spectroscopic scanning (lower). Conditions of electrophoresis were as described in the legend to Fig. 2. The gels were divided into $1-\mathrm{mm}$ slices. The protein samples which were applied to the gels were treated with $0.04 \%$ deoxycholate (A), $0.14 \%$ deoxycholate (B) and $0.42 \%$ deoxycholate $(C)$. Protein samples in the absence of deoxycholate were comparable to those incubated with $0.04 \%$ (A).

Fig. 4. Following incubation with $0.04 \%(\mathrm{w} / \mathrm{v})$ deoxycholate, the ${ }^{14} \mathrm{C}$ label coincided with the protein bands and no radioactivity was observed in the buffer front (Fig. 4A). At higher concentrations, $0.14 \%$ and $0.42 \%$ deoxycholate, the ${ }^{14} \mathrm{C}$ label shifts from the protein band to the buffer front i.e. delipidation of the exchange protein has occurred (Fig. 4B, C). The photometric scans show that with increased deoxycholate concentration the $R_{\mathrm{F}}$ value of the main protein band increases from 0.25 to 0.38 . It is of interest to note that the two protein bands observed in the absence (Fig. 2 ) or presence of $0.04 \%$ deoxycholate (Fig. $4 \mathrm{~A}$ ) have coalesced to one band with $0.42 \%$ deoxycholate (Fig. $4 \mathrm{C}$ ). After trichloroacetic acid fixation a white, opalescent band which did not stain with Coomassie Blue could be observed at the buffer front. This presumably corresponds to the position of mixed $\left[{ }^{14} \mathrm{C}\right]$ phosphatidylcholine-detergent micelles.

The relationship between deoxycholate concentration and redistribution of ${ }^{1}{ }^{4} \mathrm{C}$-label between the protein bands and the buffer front is summarized in Fig. 5. Delipidation of the exchange protein begins above $0.04 \%$ deoxycholate and is virtually complete at $0.30 \%$. It will be considered in the Discussion how the extent of delipidation may be related to the critical micelle concentration of deoxycholate and the number of micelles available.

The total radioactivity recovered from the resolving gels increases with 


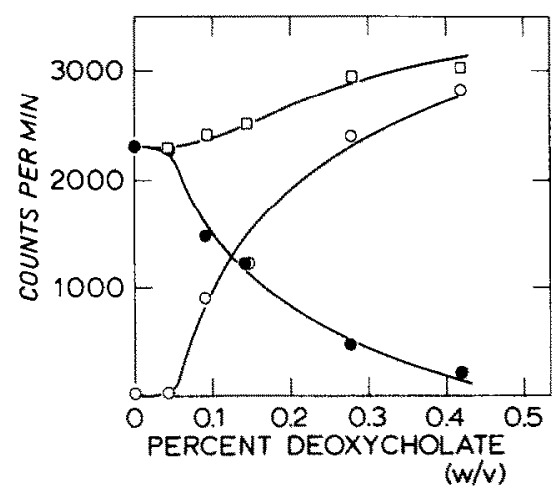

Fig. 5. The recovery of radioactivity from polyacrylamide gels after electrophoresis of I $\left.^{14} \mathrm{C}\right]$ phosphatidylcholine exchange protein as a function of the deoxycholate concentration of the protein samples applied to the gels. $0 \longrightarrow-14 \mathrm{C}$ radioactivity present in the front of the gel; $\longrightarrow$, radioactivity present in the protein bands; $\longrightarrow \square$, the total radioactivity in the resolving gel.

increasing deoxycholate concentration (Fig. 5). For example, after incubation with $0.42 \%$ deoxycholate the total radioactivity on the gel has increased by $25 \%$. This increase probably reflects the solubilizing action of deoxycholate on protein aggregates which may have been present in the samples applied to the gel. This would explain as to why the ${ }^{14} \mathrm{C}$ label representing this aggregated material and visible on top of the stacking gel with $0.04 \%$ deoxycholate (Fig. $4 \mathrm{~A}$ ), has disappeared with $0.42 \%$ deoxycholate (Fig. 4C). The tendency of the exchange protein to form aggregates has been noted [14]

\section{Effect of Triton $X-100$}

Triton X-100 is also effective in delipidating the exchange protein (Fig. 6). Delipidation is apparent with $0.09 \%$ (Fig. $6 \mathrm{~B}$ ) and is virtually complete at $0.46 \%$ (Fig. 6C). This detergent does not alter the electrophoretic mobility of the protein, although the two observed bands become more diffuse with incrcasing detergent concentration. This may be attributed to the binding of Triton X-100 to the protein.

It is interesting to note that the $\left[{ }^{14} \mathrm{C}\right]$ phosphatidylcholine released from the protein by Triton X-100 does not enter the gel. This follows from the fact that mixed Triton X-100 phosphatidylcholine micelles formed during delipidation will be electrically neutral.

\section{Effect of lysophosphatidylcholine}

The effect of lysophosphatidylcholine prepared from egg yolk phosphatidylcholine on the ${ }^{14} \mathrm{C}$-labelled exchange protein is shown in Fig. 7. The protein preparation used in this instance was not absolutely pure; another protein with an $R_{\mathrm{F}}$ value of 0.58 was present. Incubation with $0.7 \cdot 10^{-5} \mathrm{M}$ and $1.4 \cdot 10^{-5} \mathrm{M}$ lysophosphatidylcholine affects neither the electrophoretic behaviour of the protein nor the binding of $\left[{ }^{14} \mathrm{C}\right]$ phosphatidylcholine to the protein (Fig. 7A). At $2.8 \cdot 10^{-5} \mathrm{M}$ lysophosphatidylcholine, however, a part of the ${ }^{14} \mathrm{C}$ label is detected at the top of the resolving gel, while the remaining radioactivity coincides with the exchange protein in the gel (Fig. 7B). This suggests that 
A

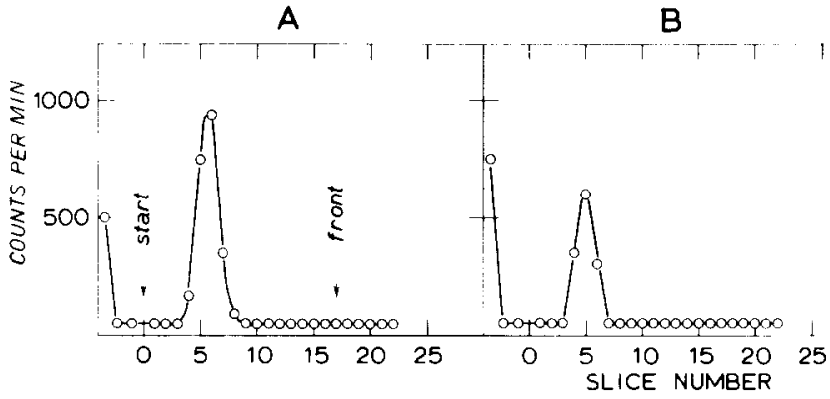

C

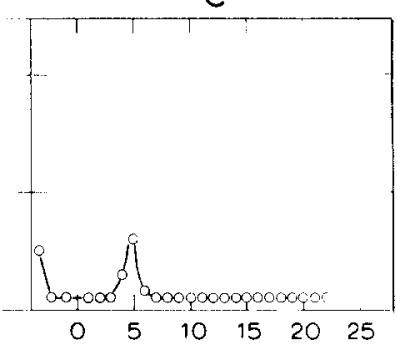

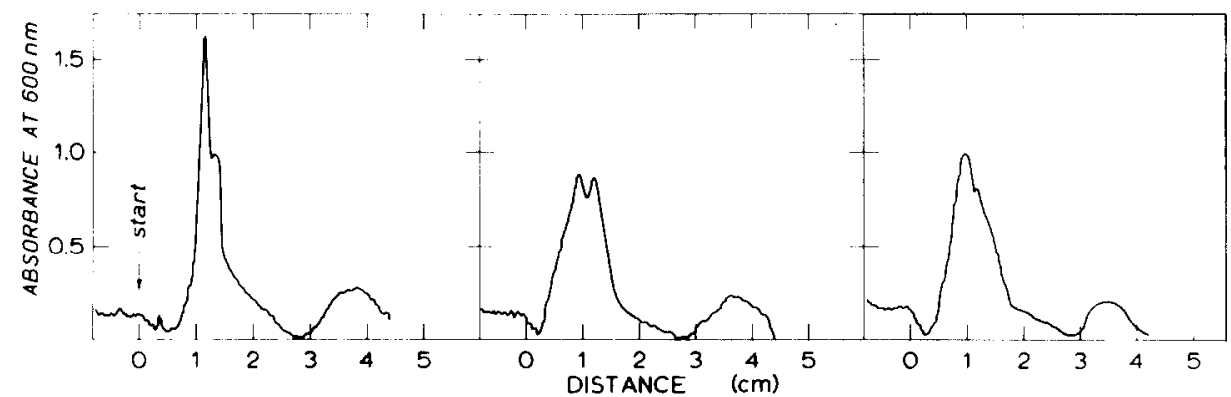

Fig. 6. Effect of Triton X-100 on $\left[{ }^{14} \mathrm{C}\right]$ phosphatidylcholine exchange protein as analyzed by tracing the radioactivity (upper) and spectroscopic scanning (lower). Conditions of electrophoresis were as described in the legend to Fig. 2 . The gels were divided into 2 -mm slices. The protein samples which were applied to the gels were incubated without Triton X-100 (A) and in the presence of $0.09 \%$ Triton X-100 (B) and $0.46 \%$ Triton X-100 (C).
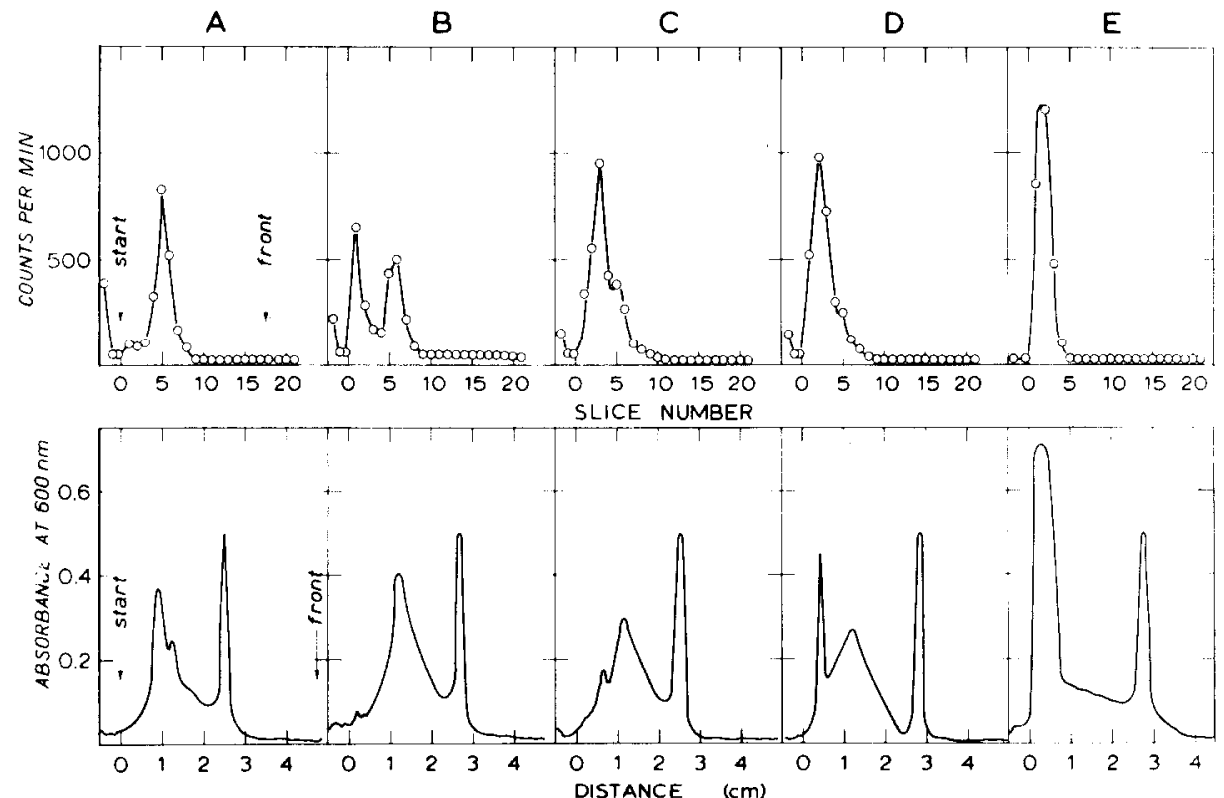

Fig. 7. Effect of lysophosphatidylcholine on $\left[{ }^{14} \mathrm{C}\right]$ phosphatidylcholine exchange protein as analyzed by tracing the radioactivity (upper) and spectroscopic scanning (lower). Conditions of electrophoresis were as described in the legend to Fig. 2. The gels were divided into $2-\mathrm{mm}$ slices. The protein samples which were applied to the gels were incubated with lysophosphatidylcholine prior to electrophoresis. The effect of $0.7 \cdot 10^{-5} \mathrm{M}$ and $1.4 \cdot 10^{-5} \mathrm{M}$ lysophosphatidylcholine is demonstrated in (A), $2.8 \cdot 10^{-5} \mathrm{M}$ in (B), $5.6 \cdot 10^{-5} \mathrm{M}$ in (C), $5 \cdot 10^{-3} \mathrm{M}$ in $(\mathrm{D})$ and $1 \cdot 10^{-2} \mathrm{M}(\mathrm{E})$. Incubations of exchange protein in the absence of lysophosphatidy lcholine gave the same result as is shown in (A). 
the lyso compound may have the potential to delipidate through the formation of mixed micelles which do not enter the resolving gel. Increasing the concentration of lysophosphatidylcholine results in all the ${ }^{14} \mathrm{C}$ label collecting the top of the resolving gel (Fig. 7C-E). However, simultaneously, the exchange protein also begins to redistribute between the original position in the gel and the top of the gel containing the micelles. In the presence of $1 \cdot 10^{-2} \mathrm{M}$ lysophosphatidylcholine the exchange protein no longer enters the gel (Fig. 7E). This may indicate that the exchange protein has become part of the mixed phosphatidylcholine-lysophosphatidylcholine micelles. The electrophoretic mobility of the contaminating protein $\left(R_{\mathrm{F}}, 0.58\right)$ is not affected under any of the above incubation conditions. This argues for the specific character of the interaction between exchange protein and micelle.

\section{Effect of sodium dodecyl sulfate}

${ }^{14}$ C-labelled exchange protein was incubated with $0.1 \%(\mathrm{w} / \mathrm{v})$ sodium dodecyl sulfate and submitted to gel electrophoresis according to the method of Davis [22]. Both the ${ }^{14} \mathrm{C}$-label and the protein collected at the buffer front. This suggests that sodium dodecyl sulfate forms a negatively charged complex with the protein which is stable to the conditions of electrophoresis. The delipidating action of this detergent is shown in Fig. 8 where the exchange protein was submitted to sodium dodecyl sulfate-polyacrylamide gel electrophoresis [24]. The $\left[{ }^{14} \mathrm{C}\right]$ phosphatidylcholine sodium dodecyl sulfate micelles migrate ahead of the front indicated by Bromophenol blue, while the delipidated protein has an electrophoretic mobility in accordance with a mol. wt of
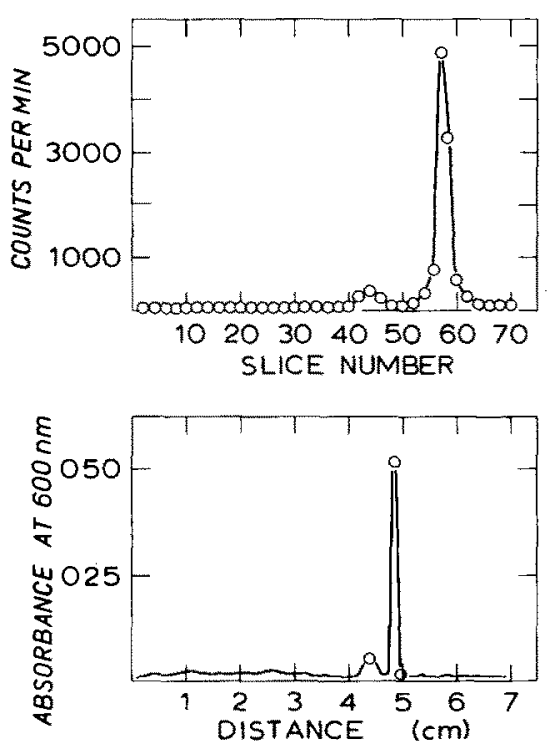

Fig. 8. Sodium dodecyl sulfate gel electrophoresis of ${ }^{14} \mathrm{C}$-labelled exchange protein. Electrophoresis was performed for $4 \mathrm{~h}$ at $5 \mathrm{~mA}$ per gel. Radioactive analysis and staining was done as described in Materials and Methods. The upper part of the figure represents the radioactive analysis. The front is indicated by slice number 52 . The lower part of the figure gives the photometric scanning. The front is located at 5.2 $\mathrm{cm}$. 
22000 [14]. Despite the harsh conditions of sodium dodecyl sulfate treatment, delipidation of the exchange protein was incomplete (Fig. 8); a small ${ }^{14} \mathrm{C}$-labelled protein band remains with a slightly lower mobility.

\section{Effect of cetyltrimethylammonium bromide}

Because of the cationic character of the detergent cetyltrimethylammonium bromide, polarity during electrophoresis was reversed, i.e., migration was towards the cathode. After incubation with $0.2,0.4$ and $0.8 \%(\mathrm{w} / \mathrm{v})$ detcrgent, both the ${ }^{14} \mathrm{C}$-label and the protein were located at the buffer front. This demonstrates that the detergent forms a strong complex with the protein and thereby conveys on overall positive charge to the complex.

\section{Exchange activity and immunological properties}

The above results indicate that detergents are able to delipidate the exchange protein. Moreover, binding of the detergents to the protein is apparent from the altered electrophoretic behaviour. It was, therefore, of interest to determine how the detergent treatment affected the exchange activity and the immunological properties of the protein.

Unlabelled exchange protein was incubated with detergents as described in Materials and Methods under conditions where delipidation was complete, i.e., $0.3 \%(\mathrm{w} / \mathrm{v})$ sodium deoxycholate, $0.5 \%(\mathrm{w} / \mathrm{v})$ Triton X-100 and $1 \cdot 10^{-4} \mathrm{M}$ lysophosphatidylcholine. Aliquots of $25 \mu \mathrm{l}$ containing $4.0 \mu \mathrm{g}$ of delipidated protein and detergent were taken and the transfer of $\left[{ }^{14} \mathrm{C}\right]$ phosphatidylcholine measured in the liposome-liposome assay. Addition of detergent to $1.5 \mathrm{ml}$ of the assay medium gave a 60 -fold dilution. The resultant detergent concentrations were found to have no effect on the assay. It is seen in Table I that the exchange protein delipidated by different detergents was not inactivated. Measuring the exchange activity of proteins treated with sodium dodecyl sulfate $(0.1 \% \mathrm{w} / \mathrm{v})$ and cetyltrimethylammonium bromide $(0.2 \% \mathrm{w} / \mathrm{v})$ posed serious problems as minute amounts $(25-50 \mu \mathrm{g})$ of these detergents damaged the liposomes in the assay.

The behaviour of detergent-treated proteir in double immunodiffusion against a $\gamma$-globulin fraction of the exchange protein antiserum is summarized

\section{TABLE I}

THE EFFECT OF DELIPIDATION BY DETERGENTS ON THE ACTIVITY OF THE EXCHANGE PROTEIN

Exchange protein $(40 \mu \mathrm{g})$ was incuabted for $30 \mathrm{~min}$ at $37^{\circ} \mathrm{C}$ in a total volume of $0.25 \mathrm{ml} 30 \%$ sucrose/ $0.01 \mathrm{M}$ Tris-HCl (pH 7.4) with $0.3 \%$ deoxycholate, $0.5 \%$ Triton $\mathrm{X}-100$ and $1 \cdot 10^{-4} \mathrm{M}$ lysophosphatidylcholine. Aliquots of $25 \mu 1$ were assayed for exchange activity in the liposome-liposome system as described in Materials and Methods.

\begin{tabular}{ll}
\hline Detergent & Transfer of $\left[{ }^{14} \mathrm{C}\right]$ phosphatidylcholine $(\%)^{*}$ \\
\hline None & 37.0 \\
Deoxycholate & 30.1 \\
Triton X-100 & 35.8 \\
Lysophosphatidylcholine & 37.0
\end{tabular}

* Values were corrected for blank incubation. 


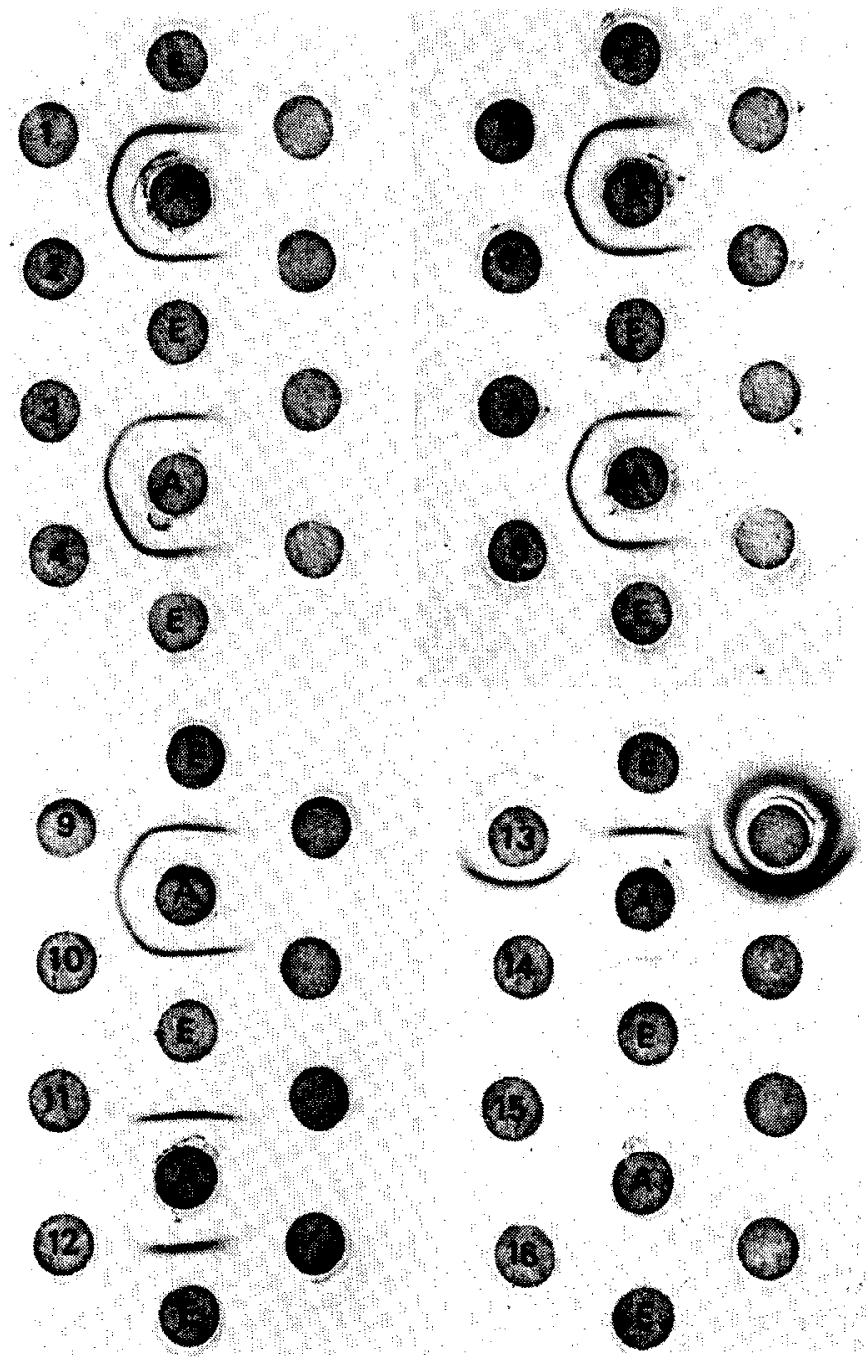

Fig. 9. Double immunodiffusion on agar of detergent treated exchange protein samples. Well A contained $125 \mu \mathrm{g}$ of a $\gamma$-globulin fraction of rabbit antiserum against the exchange protein. Well $E, 2 \mu g$ of untreated exchange protein. Wells $1-16$ contained $2 \mu \mathrm{g}$ of exchange protein in the presence of various concentrations of detergents; 1,2 and $3: 0.16 \%, 0.32 \%$ and $0.64 \%$ deoxycholate; $4,5,6$ and $7: 5.6 \cdot 10^{-5} \mathrm{M}$, $1.1 \cdot 10^{-4} \mathrm{M}, 1.6 \cdot 10^{-3} \mathrm{M}$ and $4.8 \cdot 10^{-3} \mathrm{M}$ lysophosphatidylcholine; 8,9 and $10: 0.16 \%, 0.32 \%$ and $0.64 \%$ Triton $X-100 ; 11,12$ and $13: 0.16 \%, 0.32 \%$ and $0.64 \%$ sodium dodecyl sulfate; 14,15 and 16 : $0.16 \%, 0.32 \%$ and $0.64 \%$ cetyltrimethylammonium bromide. The wells opposite the numbered wells contained only detergents in the same concentrations as mentioned above.

in Fig. 9. Protein treated with various concentrations of deoxycholate, lysophosphatidylcholine and Triton X-100 gave a single precipitin line which fused with the line of untreated protein (Wells 1-10). On the other hand, protein treated with sodium dodecyl sulfate or cetyltrimethylammonium bromide gave no precipitin lines (Wells 11-16). It is of interest to note that apparently the concentration of the latter detergent in Wells $14-16$ is sufficient to prevent the formation of precipitin lines with the untreated protein. 


\section{Discussion}

A method has been presented for the preparation of highly labelled $\left[{ }^{14} \mathrm{C}\right]$ phosphatidylcholine exchange protein. From studies with $\left[{ }^{14} \mathrm{C}\right]$ phosphatidylcholine monolayers it is known that upon injection of the exchange protein under the monolayer the protein-bound phosphatidylcholine equilibrates with the monolayer phosphatidylcholine [15]. Preparation of the ${ }^{14} \mathrm{C}$ labelled protein is based on a similar equilibration process in which the protein is incubated with liposomes containing highly labelled $\left[{ }^{14} \mathrm{C}\right]$ phosphatidylcholine. It is presumed that equilibration occurs only with the phosphatidylcholine present in the outer liposomal monolayer [27]. Approx. $70 \%$ of the total phospholipid pool constitutes the outer monolayer with single bilayer liposomes [30,31]. Knowing the amount of protein-bound phosphatidylcholine and the amount and specific activity of liposomal $\left[{ }^{14} \mathrm{C}\right]$ phosphatidylcholine one could predict how much ${ }^{14} \mathrm{C}$ label will be incorporated into the protein at equilibrium. In general, $30-70 \%$ of the expected radioactivity is found. The deviation is probably due to incomplete dispersion of liposomal phosphatidylcholine during the brief ( $2 \mathrm{~min}$ ) sonication period.

The ${ }^{14} \mathrm{C}$-labelled exchange protein could be separated from the ${ }^{14} \mathrm{C}$ labelled liposomes by chromatography on a Sephadex G-75 column (Fig. 1). Analysis of the liposome peak for exchange activity revealed that none of the exchange protein was bound to the liposomes. This was to be expected since with the uncharged phosphatidylcholine liposomes the dissociation constant of exchange protein liposome complex, would be in the order of $10^{-3} \mathrm{M}[32]$.

The single phosphatidylcholine molecule present in the protein is noncovalently bound since it can be extracted with organic solvents [14]. The present study demonstrates that detergents, both ionic and nonionic, are able to delipidate the exchange protein. Since a lipid "phase" as has been described for biological membranes [33] and serum lipoproteins [34,35] cannot exist with this protein, we must assume that the detergent monomer molecules interact with hydrophobic sites on the protein. The occurrence of such sites on the exterior of the protein is suggested by the great tendency to form aggregates [14]. Hydrophobic regions exposed to the medium are also predicted on theoretical grounds considering an average hydrophobicity of 1109 calories per amino acid residue in relation to a mol. wt of 22000 [36]. The increased solubility of the protein as is demonstrated with deoxycholate provides evidence for detergent interaction with these hydrophobic sites (Fig. 5). These interactions should precede the actual competition with the phosphatidylcholine molecule for a presumably specific hydrophobic binding site on the pro. tein. In support of this mechanism is the observation that deoxycholate below the critical micelle concentration interacts in such a manner that the phosphatidylcholine molecule on the protein becomes susceptible to phospholipase action [17].

The actual delipidation of the protein depends on the ability of a detergent to form mixed micelles containing phospholipid. In this sense micelle formation and binding of detergent to the protein are competitive processes [37]. We observed that deoxycholate does not delipidate completely at or near the critical micelle concentration, which is approx. $0.1 \%(\mathrm{w} / \mathrm{v})$. Makino et al. 
[3] have calculated that 1-3.5\% of the total amount of deoxycholate is present in the micellar form at the critical micelle concentration, yielding a concentration of $2-7 \mathrm{nmol}$ of micelles per ml. Philippot [38] has provided evidence that one micelle of deoxycholate could probably incorporate only one phospholipid molecule. Under the conditions of detergent treatment $1 \mathrm{ml}$ medium contains $4 \mathrm{nmol}$ of exchange protein. Thus, incomplete delipidation may result from an insufficient number of micelles available to accommodate all the protein-bound phosphatidylcholine. The incomplete delipidation observed with $0.09 \%$ Triton X-100 may be understood in a similar way (Fig. 6). The critical micelle concentration of Triton X-100 is approx. $0.015 \%$ [39]. The relationship between extent of delipidation and detergent concentration suggests that a dynamic equilibrium governs the redistribution of phosphatidylcholine between the protein molecules and the detergent micelles. Such a process can be thought analogous to that governing the redistribution of phosphatidylcholine between exchange protein molecules and membrane systems. Heleniums and Simons [12] reported that deoxycholate could be removed from deoxycholate-apo low density lipoprotein complexes by Sephadex gel filtration. In spite of the strongly hydrophobic character of the protein, deoxycholate apparently is not irreversibly bound. It was, therefore, surprising to find that the electrophoretic mobility of the exchange protein increased from $R_{\mathrm{F}} 0.25$ to 0.38 after incubation with $0.42 \%$ deoxycholate. Since delipidation per se does not affect the mobility, one or more deoxycholate molecules may remain strongly bound to the protein conferring additional negative charge to the complex. Such binding appears to be irreversible under the conditions of incubation; on the other hand the dissociation rate constant of the detergent-protein complex may be very low. Similarly, it appears that Triton X-100 is also tightly bound to the protein, since in comparison to the control, the protein bands become very diffuse upon electrophoresis. Binding of deoxycholate and Triton X-100, however, do not affect the conformation of the protein to the extent that antigenic determinants are lost. Double immunodiffusion in agar demonstrated that the treated protein is indistinguishable from the native protein. In contrast, protein treated with sodium dodecyl sulfate and cetyltrimethylammonium bromide gave no precipitin lines. Additional evidence for a strong interaction of these detergents with the protein is provided by the fact that the protein migrates with the buffer front, behaving either as a polyanion or polycation. It remains to be seen whether the exchange protein has high affinity binding sites comparable to the ones which have been extensively characterized for serum albu$\min [3,4]$.

Similar to the other detergents lysophosphatidylcholine seems to delipidate the exchange protein, above the critical micelle concentration which is approx. $2 \cdot 10^{-5} \mathrm{M}[40]$. However, in contrast to the other detergents, the protein itself is incorporated into the micelle at elevated lysophosphatidylcholine concentrations. Ultracentrifugal analysis and fluoresence spectroscopy have indicated that an apolipoprotein from serum high density lipoprotein [41] and the polypeptide hormones glucagon and calcitonin [42] can also interact strongly with lysophosphatidylcholine micelles. The exposure of hydrophobic sites on these proteins and polypeptides may lead to incorporation into the apolar interior of the micelle. Exchange protein and glucagon [42] do 
not incorporate into phosphatidylcholine liposomes. This difference may be due to a tighter packing of the liposomal bilayer as compared to the lysophosphatidylcholine micelle [40].

\section{Acknowledgements}

The authors thank Mr J. Westerman for his technical assistance.

\section{References}

1 Steinhardt, J. and Reynolds, J.A. (1969) Multiple Equilibria in Proteins, Academic Press, New York

2 Reynolds, J.A. and Tanford, C. (1970) J. Biol. Chem. 245, 5161-5165

3 Makino, S., Reynolds, J.A. and Tanford, C. (1973) J. Biol. Chem. 248, 4926-4932

4 Nozaki, Y., Reynolds, J.A. and Tanford, C. (1974) J. Biol. Chem. 249, 4452-4459

5 Helenius, A. and Simons, K. (1972) J. Biol. Chem. 247, 3656-3661

6 Razin, S. (1972) Biochim. Biophys. Acta 265, 241-296

7 Kagawa, Y. (1972) Biochim. Biophys. Acta 265, 297-338

8 Fngelman, D.M., Terry, T.M. and Morowitz, H.J. (1967) Biochim. Biophys. Acta 135, $381-390$

9 Razin, S, and Barash, V. (1969) FEBS Lett, 3, 217-220

10 Simons, K., Helenius, A. and Garoff, H. (1973) J. Mol. Biol. 80, 119-133

11 Kirkpatrick, F.H., Gordesky, S.E. and Marinetti, G.V. (1974) Biochim. Biophys, Acta 345, $154-161$

12 Helenius, A. and Simons, K. (1971) Biochemistry 10, 2542-2547

13 Wirtz, K.W.A., Kamp, H.H. and van Deenen, L.L.M. (1972) Biochim. Biophys. Acta 274,606-617

14 Kamp, H.H., Wirtz, K.W.A. and van Deenen, L.L.M. (1973) Biochim. Biophys. Acta 318, 313-325

15 Demel, R.A., Wirtz, K.W.A., Kamp, H.H., Geurts van Kessel, W.S.M. and van Deenen, L.L.M. (1973) Nat. New Biol. 246, 102-105

16 Wirt $z$, K.W.A. (1974) Biochim. Biophys. Acta 344, 95-117

17 Kamp, H.H., Sprengers, E.D., Westerman, J., Wirtz, K.W.A. and van Deenen. L.L.M. (1975) Biochim. Biophys. Acta $398,415-423$

18 Papahadjopoulos, D. and Miller, N. (1967) Biochim. Biophys. Acta 135, 624-638

19 Stoffel, W., Le Kim, D. and Tschung, T.S. (1971) Hoppe-Seyler's Z. Physiol. Chem, 352, 1058--1064

20 van den Bosch, H. and van Deenen, I.L.M. (1965) Biochim. Blophys. Acta 106, 326-337

21 Lowry, O.H., Rosebrough, N.J., Farr, A.L. and Randall, R.J. (1951) J. Biol. Chem, 193, 265-275

22 Davis, B.J. (1964) Ann. N.Y. Acad. Sci. 121, 404-427

23 Matsumura, T. and Noda, H. (1973) Anal. Biochem. 56, 571-576

24 Weber, K. and Osborn, M, (1969) J. Biol. Chem. 244, 4406-4412

25 Harvey, M.S., Wirtz, K.W.A., Kamp, H.H., Zegers, B.J.M. and van Deenen, L.L.M. (1973) Biochim. Biophys. Acta $323,234-239$

26 Clausen, J. (1969) Laboratory Tcchniques (Work, T.S. and Work, E., eds), Vol. 1, p. 515, North Holland, Amsterdam

27 Hellings, J.A., Kamp, H.H., Wirtz, K.W.A. and van Deenen, L.L.M. (1974) Fur. J. Biochem. 47. $601-605$

28 Determann, H. (1969) Gel Chromatography, p. 110, Springer Verlag, New York

29 Peterson, R.F. (1972) Methods in Enzymology (Colowick, S.P. and Kaplan, N.O., eds), Vol, $25, p$. 181, Academic Press, New York

30 Kornberg, R.D. and McC.onnell, H.M. (1971) Biochemistry 10, 1111-1120

31 Finer, F.G., Flook, A.G. and Hauser, H. (1972) Biochim. Biophys. Acta 260, 49-58

32 van den Besselaar, A.M.H.P., Helmkamp, G.M. and Wirtz, K.W.A. (1975) Biochemistry 14, $1852-1858$

33 Singer, S.J. and Nicholson, G.L. (1972) Science 175, 720-731

34 Mateu, L., Tardieu, A., Luzzati, V., Aggerbeck, L. and Scanu, A.M. (1972) J. Mol. Biol. 70, $105-116$

35 Assmann, G. and Brewer, H.B. (1974) Proc. Natl. Acad. Sci. U.S. 71, 1534--1538

36 Bigelow, C. (1967) J. Theoret. Biol. 16, 187-211

37 Tanford, C. (1972) J. Mol. Biol. 67, 59-74

38 Philippot, J. (1971) Biochim. Biophys. Acta 225, 201-213

39 Helenius, A. (1973) Ph.D. Thesis, University of Helsinki

40 Saunders, L. (1966) Biochim. Biophys. Acta 125, 70-74

41 Verdery, R.B. and Nichols, A.V. (1974) Biochem. Biophys, Res. Commun. 57, $1271 \quad 1278$

42 Schneider, A.B. and Edelhoch, H. (1972) J. Biol. Chem, 247, 4986-4991 